\title{
PENGARUH REKRUTMEN, PELATIHAN DAN PENGALAMAN KERJA TERHADAP KEPUASAN KERJA DAN DAMPAKNYA PADA KINERJA KARYAWAN DI PT. MARKETAMA INDAH
}

\author{
Suryono Efendi ${ }^{1}$, Ogy Winenriandhika ${ }^{2}$ \\ ${ }^{1,2}$ Universitas Nasional Jakarta \\ Email: suryono.efendi@yahoo.com
}

\begin{abstract}
Abstrak
Tujuan dari penelitian ini untuk mengetahui apakah rekrutmen, pelatihan, pengalaman kerja berpengaruh terhadap kepuasan kerja dan dampaknya terhadap kinerja karyawan. Pendekatan yang telah digunakan dalam penelitian ini adalah analisis deskriptif dan pengolahan data dengan menggunakan Structural Equation Modeling (SEM) Teknik. Sampel dari penelitian ini adalah 115 karyawan. Hasil penelitian menunjukkan bahwa rekrutmen, pelatihan, dan pengalaman kerja berpengaruh signifikan terhadap kinerja karyawan melalui kepuasan kerja. Kepuasan kerja memiliki pengaruh mediasi penuh (full mediation) antara pelatihan dengan kinerja karyawan. Dalam hal ini perusahaan dapat meningkatkan variabel-variabel yang perlu diperbaiki di masa yang akan datang.
\end{abstract}

Kata Kunci: Rekrutmen, Pelatihan, Pengalaman Kerja, Kepuasan Kerja, Kinerja.

\section{Abstract}

The purpose of this study is to see whether recruitment, training, work experience affects job satisfaction and its impact on employee performance. The approach used in this research is descriptive analysis and data processing using Structural Equation Modeling (SEM) Techniques. The sample of this study was 115 employees. The results show that recruitment, training, and work experience have a significant effect on employee performance through job satisfaction. Job satisfaction has a full mediating effect (full mediation) between training and employee performance. This company can increase the variables that need to be used in the future.

Keywords: Recruitment, Training, Work Experience, Job Satisfaction, Performance.

\section{A. PENDAHULUAN}

Kegiatan operasional suatu perusahaan sangat ditentukan oleh peran sumber daya manusia yang memadai. Sumber daya manusia (SDM) merupakan bagian yang sangat penting dan berpengaruh dalam aktivitas suatu perusahaan serta merupakan penggerak utama organisasi perusahaan, sumber daya manusia yang baik juga akan menghasilkan kinerja yang baik. Kinerja merupakan suatu yang sangat penting di dalam suatu organisasi untuk mencapai tujuannya (Rivai \& Sagala, 2010). Kinerja karyawan akan optimal apabila telah mempunyai kepuasan akan pekerjaannya. Kinerja karyawan dapat dipengaruhi beberapa hal, salah satu faktor yang mempengaruhi kinerja karyawan adalah kepuasan kerja yang dirasakan oleh karyawan. Menurut Luthans (2006) kepuasan kerja adalah, suatu keadaan emosi positif yang berasal dari penilaian akan suatu pekerjaan ataupun sebuah pengalaman kerja yang dialami oleh individu. 
Beberapa hal yang terpenting dalam aktifitas sumber daya manusia adalah rekrutmen, pelatihan, dan pengalaman. Proses rekrutmen adalah hal yang sangat penting dalam sebuah perusahaan. Rekrutmen adalah usaha mencari dan mempengaruhi tenaga kerja agar mau melamar lowongan pekerjaan yang ada dalam suatu perusahaan (Hasibuan, 2014), karena rekrutmen merupakan hal yang penting dalam pengadaan tenaga kerja, maka jika rekrutmen berhasil secara otomatis akan banyak pelamar yang memasukkan lamarannya ke perusahaan. Pantow et al. (2017) dalam penelitiannya mengungkapkan bahwa rekrutmen berpengaruh signifikan terhadap kepuasan kerja. Hasil ini menunjukkan bahwa setiap ada peningkatan dalam proses rekrutmen kepuasan akan mengalami peningkatan. Sehingga banyak organisasi berfokus pada perekrutan dan berupaya memperhatikan karyawan proaktif yang siap berkontribusi, termotivasi sendiri, dan berpikir ke depan (Puspitasasri \& Darwin, 2021).

Selain rekrutmen, pelatihan juga mempengaruhi kinerja karyawan. Pelatihan dilakukan sebagai salah satu upaya untuk meningkatkan kinerja sumber daya manusia yang merupakan suatu siklus yang harus dilakukan secara terus menerus. Karena perkembangan dan pertumbuhan suatu perusahaan harus diimbangi oleh kemampuan sumber daya manusianya. Penelitian yang dilakukan oleh Anitha dan Kumar (2016), Tabiu dan Nura (2013), Ibrahim et al. (2017) menyatakan bahwa program pelatihan memiliki dampak positif yang signifikan terhadap kinerja karyawan. Penelitian lain yang dilakukan oleh Ocen et al. (2017) juga menyatakan bahwa program pelatihan yang diberikan oleh perusahaan memiliki dampak positif yang signifikan terhadap kepuasan kerja karyawan. Akan tetapi, penelitian yang dilakukan oleh Aragon et al. (2014) menunjukkan bahwa pelatihan tidka berpengaruh signifikan terhadap kinerja karyawan.

Proses seleksi dan pelatihan yang tepat tidak cukup untuk menunjang kinerja karyawan, melainkan membutuhkan pengalaman untuk menunjang pekerjaan tersebut. Karyawan dengan pengalaman kerja akan lebih mudah melaksanakan pekerjaan, dibandingkan dengan karyawan lama dan baru tidaklah bisa disamakan (Soetjipto, 2007). Berdasarkan penelitian yang dilakukan oleh Octavianus (2018) menunjukkan bahwa terdapat pengaruh positif dan signifikan antara pengalaman kerja terhadap kinerja karyawan. Hal ini juga didukung oleh penelitian yang dilakukan oleh Vicky dan Agus (2017) bahwa pengaruh pengalaman kerja terhadap kinerja karyawan terbukti memiliki pengaruh yang positif dan signifikan.

PT. Marketama Indah atau dikenal juga dengan Enesis Group merupakan perusahaan berbentuk Perseroan Terbatas. Perusahaan ini didirikan pada tahun 1988 di Jakarta dan berbasis di Kawasan Industri, Pulo Gadung. PT. Marketama Indah bergerak di industri farmasi dengan memproduksi produk perawatan rumah tangga, perawatan pribadi dan makanan fungsional atau makanan suplemen. Dalam mengembangkan bisnis sehingga dapat mencapai kesuksesan, perusahaan selalu mengutamakan perhatian pada pengertian akan kekuatan internal perusahaan dan kemampuan mengidentifikasikan kesempatan-kesempatan eksternal yang berasal dari pasar. Apabila kinerja karyawan dapat diwujudkan dengan baik, maka akan mendukung tercapainya tujuan perusahaan secara efektif dan efisien karena akan menciptakan suasana percepatan pelaksanaan kegiatan di lingkungan PT. Marketama Indah. Namun kenyataan yang terlihat berdasarkan hasil wawancara, dalam kurun waktu tiga tahun ke belakang pencapaian kinerja karyawan PT. Marketama Indah belum mengalami peningkatan yang signifikan. Dari periode tahun 2015 menuju periode 2016 menunjukkan 
peningkatan jumlah pengerjaan proyek sebesar 69.097.665 unit, yaitu dari semula 658.420.336 unit meningkat menjadi 703.906.560 unit. Peningkatan juga terjadi pada periode selanjutnya, yaitu periode tahun 2017 sejumlah 45.486.224 unit. Jumlah peningkatan yang terjadi tidak signifikan dari semula meningkat 69.097.665 unit, menjadi 45.486.224 unit. Begitu juga pada tahun 2019, jumlah peningkatan produksi sejumlah 13.641 .828 unit, peningkatan ini jauh lebih rendah jika dibandingkan pada tahun 2016. Penurunan produksi dapat disebabkan karena banyak faktor. Dalam penelitian ini, diindikasikan bahwa penurunan produksi disebabkan karena adanya penurunan kinerja pegawai. Hal tersebut menjadi pekerjaan rumah tersendiri bagi perusahaan bagaimana meningkatkan kinerja karyawan dengan cara memperbaiki rekrutmen, pelatihan, dan pengalaman melalui kepuasan kerja pegawai.

Berdasarkan hasil penelitian terdahulu terdapat research gap yaitu perbedaan hasil dari penelitian-penelitian yang telah dilakukan, maka perlu dilakukan penelitian tentang pengaruh rekrutmen, pelatihan, dan pengalaman terhadap kinerja pegawai dengan menghadirkan variabel kepuasan kerja sebagai variabel intervening sebagai upaya untuk menutup gap tersebut. Variabel intervening dihadirkan untuk menguatkan atau memperlemah hubungan antar variabel. Menurut Hoyle (2014) menjelaskan bahwa definisi dari mediasi adalah variabel ketiga yang menghalangi hubungan variabel eksogen dengan endogen (Darwin \& Umam, 2020).

\section{B. TINJAUAN PUSTAKA}

\section{Rekrutmen}

Menurut Mathis dan Jakson (2001) rekrutmen merupakan proses yang menghasilkan sejumlah pelamar yang mempunyai kualifikasi untuk pekerjaan di suatu perusahaan atau organisasi. Ada beberapa kriteria yang perlu diperhatikan dalam perekrutan karyawan agar pelaksanaannya dapat mencapai sasaran yang diharapkan. Menurut Bambang Wahyudi kriteria perekrutan tersebut antara lain: 1) Memperhatikan petunjuk atau ketentuan dari kementerian ketenagakerjaan. 2) Kualifikasi dari pelamar, yaitu dalam hal ini perekrutan karyawan harus dilakukan dalam rangka memenuhi kebutuhan tenaga kerja dengan kualifikasi tertentu. 3) Petunjuk pimpinan, hal ini perlu diperhatikan oleh para perekrut agar calon karyawan yang diterima menepati standar perusahaan. 4) Tanggung jawab sosial, dalam hal ini perekrutan karyawan harus dilakukan dengan memperhatikan tanggung jawab sosial organisasi tersebut terhadap masyaraakat sekitar. 5) Peraturan-peraturan negara, dalam hal ini perekrutan karyawan dilakukan dengan memperhatikan ketentuan-ketentuan yang ditetapkan oleh negara melalui beberapa macam peraturan, yaitu ; usia minimal, upah minimal, waktu kerja dan sebagainya.

\section{Pelatihan}

Pengertian pelatihan secara sederhana didefinisikan oleh Chrisogonus D. Pramudyo (2007) sebagai proses pembelajaran yang dirancang untuk mengubah kinerja orang dalam melakukan pekerjaannya. pelatihan dilakukan sebagai salah satu upaya untuk meningkatkan kinerja sumber daya manusia, yang merupakan suatu proses yang harus dilakukan secara terus menerus. Karena perkembangan perusahaan juga harus diimbangi dengan kemampuan sumber daya manusianya. Seiring berkembangnya sebuah bisnis, maka kinerja pekerja dalam 
suatu perusahaan harus terus seirama dengan kemajuan dan perkembangan perusahaan. Terdapat beberapa dimensi dan indikator dalam pelatihan seperti yang akan dijelaskan oleh Mangkunegara (2011), indikator-indikator pelatihan tersebut yaitu nstruktur, peserta, materi, metode, dan tujuan.

\section{Pengalaman}

Pengalaman merupakan sesuatu yang pernah dialami, dijalani maupun dirasakan, baik sudah lama maupun yang baru saja terjadi (Mapp dalam Saparwati,2012). Setiap individu memiliki pengalaman yang berbeda walaupun melihat suatu objek yang sama, hal ini dipengaruhi oleh tingkat pengetahuan dan pendidikan seseorang, pelaku atau faktor pada pihak yang mempunyai pengalaman, faktor objek/target yang dipersepsikan serta faktor situasi dimana pengalaman itu dilakukan. Umur, latar belakang sosial ekonomi, tingkat pendidikan, budaya, pekerjaan, lingkungan fisik, kepribadian dan pengalaman hidup setiap individu juga ikut menentukan pengalaman. (Notoatmojo dalam Saparwati,2012). Menurut Foster Bill (2001), beberapa hal juga bisa menentukan berpengalaman tidaknya seorang karyawan yang sekaligus sebagai indikator pengalaman kerja yaitu: Lama waktu/masa kerja, tingkat pengetahuan dan keterampilan yang dimiliki, serta penguasaan terhadap pekerjaan dan peralatan.

\section{Kepuasan Kerja}

Menurut Robbins (2003) kepuasan kerja merupakan sikap umum terhadap pekerjaan seseorang yang menunjukkan perbedaan antara jumlah penghargaan yang diterima pekerja dan jumlah yang mereka yakini seharusnya mereka terima. Terdapat lima faktor yang bisa mempengaruhi kepuasan kerja menurut Kreitner dan Kinicki (2001) yaitu: pemenuhan kebutuhan (need fulfillment), perbedaan (discrepancies), pencapaian nilai (value attainment), keadilan (equity), komponen genetik (genetic components). Menurut Luthans (1998) ada beberapa indikator kepuasan kerja yang dapat digunakan untuk mengungkapkan karakteristik penting mengenai pekerjaan, dimana orang dapat meresponnya. indikator itu adalah: pekerjaan itu sendiri (work it self), atasan (supervision), teman sekerja (workers), promosi (promotion), gaji/upah (pay).

\section{Kinerja Karyawan}

Menurut Sedarmayanti (dalam Efendi \& Maharani, 2017), kinerja merupakan has1l kerja yang dicapai Oleh seseorang atar sekelompok orang di suatu organisasi sesuai dengan wewenang dan tanggung jawab masing-masing sebagi upaya untuk mentapai tujuan organisasi. Menurut Mathis\& Jackson (2011) penialian kerja merupakan proses mengevaluasi seberapa baik karyawan melakukan pekerjaannya jika dibandingkan dengan seperangkat standar, kemudian mengomunikasikan informasi tersebut pada karyawan. Untuk memudahkan penilaian kinerja karyawan, standar pekerjaan harus dapat diukur dan dapat dipahami secara jelas. Menurut Binangun (2012), indikator kinerja dapat diukur dengan: jumlah pekerjaan, kualitas pekerjaan, ketepatan waktu, kehadiran, dam kemampuan kerjasama. 


\section{METODE}

Penelitian ini menggunakan metode kuantitatif yang bertujuan untuk menguji hipotesis mengenai hubungan sebab-akibat antara variable motivasi kerja, kompetensi, kompensasi, kepuasan kerja dan kinerja karyawan. Teknik pengumpulan data yang dilakukan dalam penelitian ini adalah dengan menggunakan kuesioner. Teknik pengambilan sampel menggunakan purposive sample. Teknik ini merupakan cara mengambil subjek bukan didasarkan atas strata, random, atau daerah melainkan didasarkan atas adanya tujuan tertentu (Arikunto, 2010:183). Jumlah sampel dalam penelitian ini adalah 115 pegawai. Metode analisis yang digunakan dalam penelitian ini adalah metode analisis kuantitatif dengan menggunakan Structural Equation Model (SEM) melalui software AMOS versi 22. Dalam penelitian ini, jenis data yang disajikan adalah data primer dan data skunder.

\section{HASIL DAN PEMBAHASAN}

\section{Respesifikasi Model}

Menurut Haryono (2016) dalam (Nurwulandari \& Darwin, 2020) dalam bukunya yang mengungkapkan bahwa respesifikasi model bisa dilakukan setelah uji kecocokan (GOF) Dilakukan. Jika Goodness of fit index tidak sesuai dengan cut off value yang diharapkan, menurut (Fernandes et al., 2010), perlu dilakukan upaya pengkorelasian measuremen errornya berdasarkan modification indices selain akan menjadikan model semakin baik, juga dapat digunakan dan dikembangkan untuk mengetahui pengaruh korelasi antar measurement error dalam variabel eksogen dan endogen, serta pengaruh korelasi measurement error antar variabel eksogen terhadap koefisien struktural.

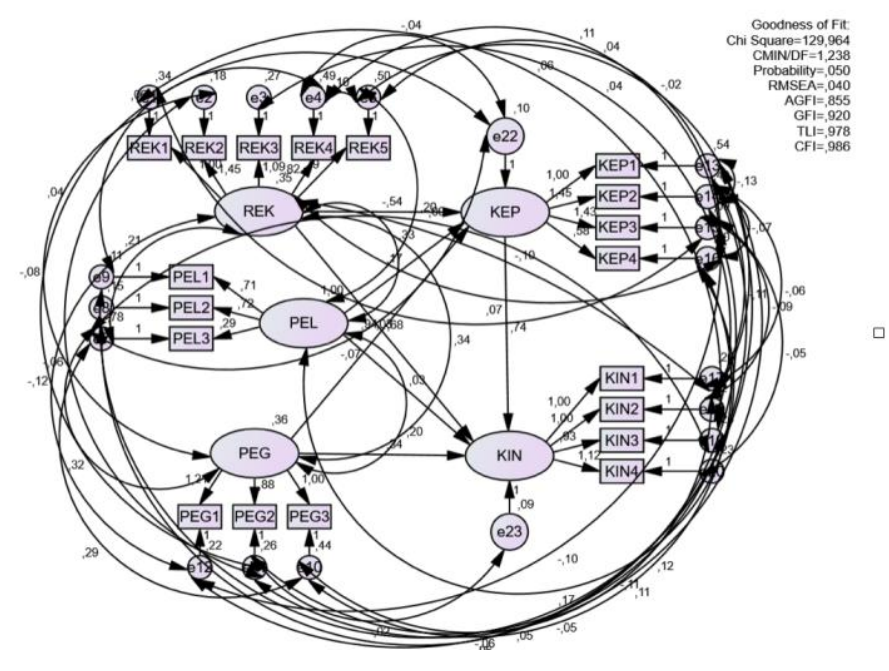

\section{Gambar 1 Full Model Structural Equation Modeling Setelah Respesifikasi Model}

Pada hasil proses respesifikasi diatas menunjukkan hasil analisis yang akan disesuaikan dengan cut off value Goodness of fit index. Hasilnya adalah goodness of fit yang sangat baik sesuai dengan cut off value yang diharapkan. Semua index GOF menghasilkan evaluasi model yang fit dan marginal fit pada index AGFI. Maka pada analisis penelitian ini dpat disimpulkan sudah memiliki kelayakan model atas data yang dikumpulkan dari responden. 


\section{Uji Pengaruh Langsung}

Hipotesis dinyatakan diterima jika CR diatas 1,96 dengan nilai probability $\mathrm{p}<0,05$. Hasil analisis pada tabel dibwah ini, menyatakan bahwa semua pengaruh langsung diterima secara signifikan, kecuali pengaruh langsung pelatihan ke kinerja menghasilkan nilai CR 0,590 dan $\mathrm{P}$ value 0,556, menyimpulkan bahwa pengaruh langsung pada hipotesis ini ditolak.

\section{Tabel 1 Regression Weights}

\begin{tabular}{|c|c|c|c|c|c|c|c|}
\hline \multicolumn{3}{|c|}{ Hipotesis } & Estimate & S.E. & C.R. & $\mathrm{P}$ & Label \\
\hline KEP & $<--$ & REK & 0,537 & 0,163 & 3,287 & 0,001 & par_16 \\
\hline KEP & $<---$ & PEL & 0,167 & 0,053 & 3,134 & 0,002 & par_18 \\
\hline KEP & $<---$ & PEG & 0,942 & 0,190 & 4,968 & $* * *$ & par_20 \\
\hline KIN & $<--$ & REK & 0,680 & 0,151 & 4,513 & $* * *$ & par_17 \\
\hline KIN & $<--$ & PEL & 0,031 & 0,052 & 0,590 & 0,556 & par_19 \\
\hline KIN & $<---$ & PEG & 0,340 & 0,142 & 2,405 & 0,016 & par_21 \\
\hline KIN & $<---$ & KEP & 0,740 & 0,188 & 3,940 & $* * *$ & par_22 \\
\hline
\end{tabular}

Sumber: Hasil Olah Data Amos 2021

\section{Uji Pengaruh Tidak Langsung}

Untuk mengetahui pengaruh tidak langsung variabel eksogen ke variabel enogen melalui interveningnya. Maka diperlukan kalkulasi uji sobel. Dari output olah data Amos pada Regression Weight dapat dihitung uji sobel yang akan menghasilkan nilai pengaruh tidak langsung. Diagram dan Formula Nilai Uji Sobel dibwah ini menunjukkan bahwa pengaruh tidak langsung menghasilkan evaluasi diterima untuk semua hipotesis.

Tabel 2 Kalkulasi Uji Sobel

\begin{tabular}{|c|c|c|c|c|c|c|c|c|c|}
\hline H & a & b & SEa & SEb & CR & Batasan & P & Batasan & Kesimpulan \\
\hline H8 & 0,537 & 0,74 & 0,163 & 0,188 & 2,526 & $>1,96$ & 0,012 & $<0,05$ & Diterima \\
\hline H9 & 0,167 & 0,74 & 0,053 & 0,188 & 2,46 & $>1,96$ & 0,013 & $<0,05$ & Diterima \\
\hline H10 & 0,942 & 0,74 & 0,19 & 0,188 & 3,083 & $>1,96$ & 0,002 & $<0,05$ & Diterima \\
\hline
\end{tabular}

Sumber: Hasil Olah Data Amos 2021

Berdasarkan tabel diatas, didapatkan hasil bahwa rekrutmen berpengaruh positif dan nyata terhadap kepuasan kerja di PT. Marketama Indah, hal ini didasarkan pada nilai $\mathrm{CR}=3,287$ atau $\mathrm{CR}$ diatas 1,96 dan $\mathrm{p}=0,001$ atau $\mathrm{p}<0,05$, hal ini berarti $\mathrm{H} 1$ diterima. Hal ini terbukti dari indeks variabel rekrutmen yang termasuk kategori tinggi, responden setuju bahwa rekrutmen yang telah dilakukan oleh PT. Marketama Indah telah sesuai dengan peraturan perundang-undangan dan kualifikasi pelamar telah ditetapkan kriteria pengekrutan. Meningkatnya kualitas rekrutmen akan meningkatkan kepuasan kerja. Hasil ini sejalan dengan hasil penelitian yang dilakukan oleh Pantow (2017) yang menunjukkan bahwa rekrutmen berpengaruh signifikan terhadap kepuasan kerja. Hal ini juga sejalan dengan penelitian yang dilakukan oleh Wijaya (2017) yang menunjukkan hasil bahwa rekrutmen mempunyai pengaruh yang positif dan signifikan terhadap kepuasan kerja.

Berdasarkan tabel di atas, didapatkan hasil bahwa pelatihan berpengaruh positif dan nyata terhadap kepuasan kerja di PT. Marketama Indah, hal ini didasarkan pada nilai $\mathrm{CR}=3,134$ atau $\mathrm{CR}$ diatas 1,96 dan $\mathrm{p}=0,002$ atau atau $\mathrm{p}<0,05$, hal ini berarti $\mathrm{H} 2$ diterima. Hal ini terbukti dari hasil kuesioner responden yang menunjukkan bahwa variabel pelatihan kerja termasuk kategori tinggi, artinya responden setuju bahwa metode pelatihan sudah sesuai 
dengan materi pelatihan yang disampaikan. Hasil ini didukung oleh penelitian yang dilakukan oleh Pahore and Shaikh (2011) yang menemukan bahwa pelatihan kerja secara positif dan signifikan terhadap kepuasan kerja. Dari penelitian Adriyan (2018) juga ditemukan hasil bahwa pelatihan berpengaruh positif dan signifikan terhadap kepuasan kerja, berarti bahwa semakin baik pelatihan akan menyebabkan tingginya kepuasan kerja karyawan. Penelitian yang dilakukan oleh Pahore dan Shaikh (2011) menunjukkan bahwa pelatihan kerja secara positif dan signifikan mempengaruhi kepuasan kerja. Penelitian serupa juga dilakukan oleh Gritama (2014) yang menunjukkan bahwa pelatihan memberikan pengaruh hasil yang positif dan signifikan terhadap kepuasan kerja.

Berdasarkan tabel di atas didapatkan hasil bahwa pengalaman berpengaruh positif dan nyata terhadap kepuasan kerja di PT. Marketama Indah, hal ini didasarkan pada nilai CR = 4,968 atau CR diatas 1,96 dan $\mathrm{p}=0,000$ atau $\mathrm{p}<0,05$, hal ini berarti H3 diterima. Hal ini terbukti dari hasil kuesioner responden yang menunjukkan hasil bahwa variabel pengalaman termasuk kategori tinggi, artinya responden setuju bahwa karyawan sudah memiliki pengetahuan dan keterampilan tentang pekerjaan yag diberikan oleh perusahaan. Hasil penelitian ini ditunjang oleh penelitian yang dilakukan oleh Richadsen dkk (1996) yang mendapatkan hasil bahwa pengalaman kerja secara signifikan berhubungan dengan kepuasan, tetapi tidak untuk dianggap kesempatan untuk kemajuan karir. Penelitian serupa juga dilakukan oleh Lubis (2019) yang menunjukkan hasil bahwa pengalaman mempunyai pengaruh yang positif dan signifikan terhadap kepuasan kerja. Hasil penelitian ini ditunjang oleh penelitian yang dilakukan oleh Wijaya \& Suana (2014) dengan menyatakan bahwa semakin banyak pengalaman, maka tingkat kepuasan kerja akan semakin tinggi. Hal ini juga terlihat pada responden di PT. Marketama Indah yang menunjukkan $61 \%$ responden sudah bekerja selama 5-10 tahun, dan 23\% bekerja lebih dari 10 tahun.

Berdasarkan tabel di atas didapatkan hasil bahwa pengalaman berpengaruh positif dan nyata terhadap kinerja karyawan di PT. Marketama Indah, hal ini didasarkan pada nilai $\mathrm{CR}=$ 4,513 atau CR diatas 1,96 dan $\mathrm{P}=0,000$ atau $\mathrm{p}<0,05$, hal ini berarti $\mathrm{H} 4$ diterima. Hal ini sejalan dengan penelitian yang dilakukan Aziz (2017) yang menunjukkan bahwa rekrutmen berpengaruh signifikan terhadap kinerja. Penelitian yang dilakukan oleh Nurhayati (2016) terkait pengaruh dari pelaksanaan rekrutmen terhadap kinerja, setelah dilakukan analisis melalui uji statistic menunjukan bahwa apabila rekrutmen ditingkatkan maka akan menimbulkan peningkatan terhadap kinerja karyawan. Hasil ini juga didukung oleh penelitian yang dilakukan Aziz (2017) yang menunjukkan bahwa rekrutmen berpengaruh signifikan terhadap kinerja. Penelitian serupa juga dilakukan oleh Potale, Lengkong, dan Moniharapon (2016) yang menunjukkan hasil bahwa terdapat pengaruh yang positif dan signifikan antara rekrutmen terhadap kinerja karyawan. Penelitian yag dilakukan oleh Hindriani (2018) menunjukkan hasil bahwa rekrutmen berpengaruh signifikan terhadap kinerja karyawan.

Berdasarkan tabel di atas didapatkan hasil bahwa pengalaman berpengaruh positif tidak nyata terhadap kinerja karyawan di PT. Marketama Indah, hal ini didasarkan pada nilai $\mathrm{CR}=0,590$ atau $\mathrm{CR}$ diatas 1,258 dan $\mathrm{P}=0,556$ atau $\mathrm{p}>0,05$, hal ini berarti H5 ditolak. Hal ini mengindikasikan bahwa peningkatan pelatihan yang di PT. Marketama Indah belum mengakibatkan peningkatan kinerja karyawan. Jika dilihat dari jawaban responden pada kueisoner, 6\% responden tidak setuju bahwa peserta pelatihan memiliki latar belakang pekerjaan yang sama, dan $6 \%$ tidak setuju bahwa pelatihan yang dilaksanakan sudah sesuai 
dengan tujuan penelitian yang ingin dicapai. Hal ini sejalan dengan penelitian yang dilakukan oleh Citra, Taher, dan Hamidah (2015) menunjukkan hasil bahwa pelatihan berpengaruh positif tidak signifikan terhadap kinerja karyawan. Sehingga dapat disimpulkan bahwa pelatihan yang baik dapat meningkatkan kinerja karyawan, namun ketidak sesuai metode pelatihan dengan materi yang dibawakan dalam melaksanan pelatihan dapat menurunkan kinerja karyawan. Penelitian yang dilakukan oleh Aragon, et al (2014) juga menunjukkan bahwa pelatihan tidak berpengaruh signifikan terhadap kinerja karyawan.

Berdasarkan tabel di atas didapatkan hasil bahwa pengalaman berpengaruh negatif dan tidak nyata terhadap kinerja karyawan di PT. Marketama Indah, hal ini didasarkan pada nilai $\mathrm{CR}=2,405$ atau $\mathrm{CR}$ diatas 1,258 dan $\mathrm{P}=0,016$ atau $\mathrm{p}<0,05$, hal ini berarti H6 diterima. Hal ini mengindikasikan bahwa semakin tinggi pengalaman yang dimiliki oleh karyawan PT. Marketama Indah, akan semakin tinggi kinerja karyawannya. Hal ini sejalan dengan penelitian yang dilakukan oleh Zahro, Suyadi, dan Djaja (2018) yang mendapatkan hasil bahwa pengalaman mempunyai pengaruh positif dan signifikan terhadap kinerja karyawan. Hal ini juga didukung dengan teori Robbins danTimothy (dalam Aristarini (2014), bahwa pengalaman kerja berpengaruh positif terhadap kinerjakaryawan. Artinya semakin banyakpengalaman kerja, maka kinerja karyawan semakin tinggi. Sebaliknya semakin sedikit pengalaman kerja, maka kinerjakaryawan juga semakin rendah.

Berdasarkan tabel di atas didapatkan hasil bahwa pengalaman berpengaruh positif dan nyata terhadap kinerja karyawan di PT. Marketama Indah, hal ini didasarkan pada nilai $\mathrm{CR}=3,940$ atau $\mathrm{CR}$ diatas 1,258 dan $\mathrm{P}=0,000$ atau $\mathrm{p}<0,05$, hal ini berarti $\mathrm{H} 7$ diterima. Hal ini mengindikasikan bahwa kepuasan kerja yang dirasakan oleh karyawan PT. Marketama Indah akan meningkatkan kinerja karyawannya. Hasil penelitian ini didukung oleh penelitian yang dilakukan oleh Hasil penelitian dari Sugiono \& Fitriana (2018) menunjukkan bahwa kepuasan kerja beperngaruh positif terhadap kinerja pegawai di BPSDM ESDM Kementerian ESDM RI.

Berdasarkan tabel di atas didapatkan hasil bahwa rekrutmen berpengaruh positif dan tidak nyata terhadap kinerja karyawan melalui kepuasan kerja di PT. Marketama Indah, hal ini didasarkan pada nilai $\mathrm{CR}=2,526$ atau $\mathrm{CR}$ diatas 1,258 dan $\mathrm{P}=0,012$ atau $\mathrm{p}<0,05$, hal ini berarti H8 diterima. Hal ini berarti semakin baik kualitas rekrutmen yang diterapkan oleh PT. Marketama Indah maka semakin meningkat tingkat kepuasan karyawan. Hal ini terbukti dari indeks variabel rekrutmen, kepuasan kerja dan kinerja karyawan yang termasuk dalam kategori tinggi. Responden setuju bahwa rekrutmen yang telah dilakukan oleh PT. Marketama Indah telah sesuai dengan peraturan perundang-undangan. Meningkatnya kualitas rekrutmen akan meningkatkan kepuasan kerja yang berdampak pada kinerja karyawan. Berdasarkan pada perhitungan VAF, didapatkan nilai bahwa pengaruh mediasi dari kepuasan kerja antara variabel rekrutmen dan kinerja karyawan yaitu 36\% (partial mediation).

Berdasarkan tabel di atas didapatkan hasil bahwa pelatihan berpengaruh positif dan nyata terhadap kinerja karyawan melalui kepuasan kerja di PT. Marketama Indah, hal ini didasarkan pada nilai $\mathrm{CR}=2,460$ atau $\mathrm{CR}$ diatas 1,258 dan $\mathrm{P}=0,013$ atau $\mathrm{p}<0,05$, hal ini berarti H9 diterima. Hal ini menandakan bahwa jika terjadi peningkatan pelatihan melalui kepuasan kerja di PT. Marketama Indah akan meningkatkan kinerja karyawan. Hal ini terbukti dari indeks variabel pelatihan, kepuasan kerja, dan kinerja karyawan yang termasuk dalam kategori tinggi. Responden setuju bahwa peserta pelatihan yang dilaksanakan oleh PT. 
Marketama Indah mempunyai latar belakang yang sama, hal ini berarti pelatihan yang dilakukan PT. Marketama Indah mampu meningkatkan kepuasan kerja yang berdampak pada kinerja karyawan. Berdasarkan pada perhitungan VAF, didapatkan nilai bahwa pengaruh mediasi dari kepuasan kerja antara variabel pelatihan dan kinerja karyawan yaitu $81 \%$ (full mediation). Hal ini membuktikan bahwa pengaruh tidak langsung pelatihan terhadap kinerja karyawan lebih besar daripada pengaruh secara langsung. Oleh Karena itu penting untuk dipastikan bahwa pelatihan harus menciptakan terjadinya peningkatan kepuasan kerja, dengan demikian akan menyebabkan terjadinya peningkatan kinerja karyawan.

Berdasarkan tabel di atas didapatkan hasil bahwa pelatihan berpengaruh positif dan nyata terhadap kinerja karyawan melalui kepuasan kerja di PT. Marketama Indah, hal ini didasarkan pada nilai $\mathrm{CR}=3,083$ atau $\mathrm{CR}$ diatas 1,258 dan $\mathrm{P}=0,002$ atau $\mathrm{p}<0,05$, hal ini berarti H10 diterima. Hal ini membuktikan bahwa pengaruh pengalaman terhadap kinerja karyawan secara tidak langsung mempunyai pengaruh positif dan signifikan. Hal ini mendandakan bahwa peningkatan pengalaman melalui kepuasan kerja di PT. Marketama Indah, maka kinerja karyawan juga akan mengalami peningkatan. Hal ini terbukti dari variabel pengalaman, kepuasan kerja, dan kinerja karyawan yang termasuk dalam kategori tinggi. Responden setuju bahwa mereka telah memiliki tingkat pengetahuan dan keterampil;an yang sesuai dengan bidang pekerjaannya. Meningkatnya tingkat pengalaman karyawan PT. Marketama Indah akan meningkatkan kepuasan kerja yang berdampak kepada kinerja karyawan. Berdasarkan pada perhitungan VAF, didapatkan nilai bahwa pengaruh mediasi dari kepuasan kerja antara variabel pengalaman kerja dan kinerja karyawan yaitu $56 \%$ (partial mediation).

\section{E. KESIMPULAN}

Hasil penelitian menunjukkan bahwa rekrutmen, pelatihan, dan pengalaman kerja berpengaruh signifikan terhadap kinerja karyawan melalui kepuasan kerja. Kepuasan kerja memiliki pengaruh mediasi penuh (full mediation) antara pelatihan dengan kinerja karyawan. Dalam hal ini perusahaan dapat meningkatkan variabel-variabel yang perlu diperbaiki di masa yang akan datang, seperti pembenahan terhadap metode rekrutmen yang ada, peningkatan kualitas pelatihan, dan juga memperhatikan pengalaman kerja yang dimiliki karyawan untuk kemudian meningkatkan kinerja karyawannya.

\section{DAFTAR PUSTAKA}

Anitha, R., \& Kumar, M. A. (2016). A study on the impact of training on employee performance in private insurance sector, Coimbatore district. International Journal of Management Research and Reviews, 6(8), 1079.

Aragón, M. I. B., Jiménez, D. J., \& Valle, R. S. (2014). Training and performance: The mediating role of organizational learning. BRQ business research quarterly, 17(3), 161-173.

Arikunto, S. 2010. Prosedur Penelitian Suatu Pendekatan Praktik. Jakarta: Rineka Cipta.

Aristarini, L., Kirya, I. K., \& Yulianthini, N. N. (2014). Pengaruh pengalaman kerja, kompetensi sosial \& motivasi kerja terhadap kinerja karyawan pada bagian pemasaran PT Adira Finance Singaraja. Jurnal Manajemen, 2. 
Aziz, T. A., Maarif, M. S., \& Sukmawati, A. (2017). Pengaruh rekrutmen dan seleksi terhadap kinerja. Jurnal Aplikasi Bisnis dan Manajemen (JABM), 3(2), 246-246.

Binangun, W. (2012). Manajemen Sumber Daya Manusia. Jakarta: Erlangga.

Brahmasari, I. A., \& Suprayetno, A. (2008). Pengaruh motivasi kerja, kepemimpinan dan budaya organisasi terhadap kepuasan kerja karyawan serta dampaknya pada kinerja perusahaan (Studi kasus pada PT. Pei Hai International Wiratama Indonesia). Jurnal Manajemen dan Kewirausahaan (Journal of Management and Entrepreneurship), 10(2), 124-135.

Darwin, M., \& Umam, K. (2020). Analisis Indirect Effect pada Structural Equation Modeling: Studi Komparasi Penggunaan Software Amos dan SmartPLS. NUCLEUS, 1(2), 50-57.

Djumadi. (2006). Pengaruh Kondisi Kerja dan Kepuasan Kerja Terhadap Kinerja Karyawan Lembaga Pendidikan Non formal di Jawa Timur. Jurnal Aplikasi Manajemen, 4(3), 411-420.

Foster, B. (2001). Pembinaan untuk Peningkatan Kinerja Karyawan. Jakarta: PPM.

Ghozali, I. (2016). Aplikasi Analisis Multivariete dengan Program SPSS. Semarang: Badan Penerbit Universitas Diponegoro.

Ghozali, I. (2017). Model Persamaan Struktural Konsep Dan Aplikasi. Dengan Program AMOS 24. Semarang: Badan Penerbit Universitas Diponegoro.

Ghozali, I., \& Latan, H. (2014). Partial Least Square Konsep Metode dan Aplikasi Penggunaan WarpPLS 4.0. Semarang Badan Penerbit UNDIP.

Giritama, I. P. C., \& Suana, I. W. (2014). Pengaruh Pelatihan kerja dan Kompensasi Terhadap Kepuasan Kerja Serta Dampaknya Terhadap Prestasi Kerja Karyawan Koperasi Serba Usaha Kuta Mimba Di Kuta-Badung. E-Jurnal Manajemen, 3(4).

Hasibuan, M. S. P. (2014). Manajemen Sumber Daya Manusia. Jakarta: Bumi Aksara.

Hindriari, R. (2018). Pengaruh Rekrutmen Dan Seleksi Terhadap Kinerja Karyawan Pada PT. Boga Lestari Sentosa. JENIUS (Jurnal Ilmiah Manajemen Sumber Daya Manusia), 2(1).

Ibrahim, R., Boerhannoeddin, A., \& Bakare, K. K. (2017). The effect of soft skills and training methodology on employee performance. European Journal of Training and Development, 41(4), 388-406.

Koesmono, H. T. (2005). Pengaruh budaya organisasi terhadap motivasi dan kepuasan kerja serta kinerja karyawan pada sub sektor industri pengolahan kayu skala menengah di Jawa Timur. Jurnal manajemen dan kewirausahaan, 7(2), 171-188.

Kreitner, R., \& Kinicki, A. (2001). Organizational Behavior. New York: McGraw-Hill Companies, Inc.

Lubis, L. (2017). Pengaruh Pengalaman Kerja Dan Lingkungan Kerja Terhadap Kepuasan Kerja Karyawan Pada PTPN VII Unit Kedaton (Doctoral Dissertation, IBI Darmajaya).

Luthans, F. (2006). Perilaku Organisasi. Yogyakarta: Andi.

Maharani, I., \& Efendi, S. (2019). Pengaruh Budaya Organisasi, Komitmen Organisasi, Kompensasi, Dan Etos Kerja Terhadap Kinerja Pegawai Kementerian Ketenagakerjaan Republik Indonesia. Oikonomia: Jurnal Manajemen, 13(2). 
Mangkunegara, A. A. A. P. (2013). Manajemen Sumber Daya Manusia untuk Perusahaan. Bandung: Remaja Rosda Karya.

Mathis, R. L., \& Jackson, J. H. (2001). Human Resource Management. Jakarta: Salemba Empat.

Mathis, R. L. \& Jackson, J. H. (2009). Manajemen Sumber Daya Manusia. Jakarta: Salemba Empat.

Ningsi, C. A., Alhabsji, T., \& Utami, H. N. (2016). Pengaruh Pelatihan Dan Promosi Terhadap Motivasi Dan Kinerja Karyawan (Studi Pada Karyawan Pt. pln (Persero) Area Kendari). Jurnal Ilmiah Ilmu Administrasi Publik, 5(2), 131-143.

Notoatmodjo, S. (2010). Metodologi Penelitian Kesehatan. Jakarta: Rineka Cipta.

Nurulhadi, H. (2018). Pengaruh Rekrutmen, Seleksi, Dan Kepuasan Kerja Terhadap Kinerja Karyawan PT Aseli Dagadu Djokdja (Skripsi Universitas Islam Indonesia).

Nurhayati, T., \& Soebrantas, C. B. W. J. H. (2016). Pengaruh Rekrutmen Terhadap Kinerja Karyawan (Studi Kasus Pada Hotel Bintang Lima Pekanbaru). Jurnal Online Mahasiswa Fakultas Ilmu Sosial dan Ilmu Politik, 3(1), 4-5.

Nurwulandari, A., \& Darwin, M. (2020). Heywood Case Data Statistik: Menggunakan Teknik Respesifikasi Model. Nucleus, 1(2), 74-84.

Ocen, E., Francis, K., \& Angundaru, G. (2017). The role of training in building employee commitment: the mediating effect of job satisfaction. European Journal of Training and Development, 41(9), 742-757.

Octavianus, W. R. (2018). Pengaruh Pengalaman Kerja Dan Pelatihan Kerja Terhadap Kinerja Karyawan PT. Telkom Indonesia Cabang Manado. Jurnal EMBA: Jurnal Riset Ekonomi, Manajemen, Bisnis dan Akuntansi, 6(3).

Pahore, N. A., \& Shaikh, F. M. (2011). Analysis-Impact of Training and Development on Performance and Job Satisfaction among Higher Secondary School Teachers-A case study of Sindh. New Horizons, 5(1), 34.

Pantow, G., Dotulong, L. O., \& Walangitan, M. D. (2017). Pengaruh Rekrutmen, Gaya Kepemimpinan Dan Pengembangan Individu Terhadap Kepuasan Kerja di Freshmart Bahu Manado. Jurnal EMBA: Jurnal Riset Ekonomi, Manajemen, Bisnis dan Akuntansi, 5(3).

Potale, B. R. (2016). Pengaruh proses rekrutmen dan seleksi terhadap kinerja karyawan pada PT bank SULUTGO. Jurnal Berkala Ilmiah Efisiensi, 16(4).

Purwanto, V. A., \& Hermani, A. (2017). Pengaruh Pengalaman Kerja dan Disiplin Kerja Terhadap Kinerja Karyawan CV. Bintang Utama Semarang Bagian Body Repair. Jurnal Ilmu Administrasi Bisnis, 6(2), 19-28.

Puspitasari, A. S. A., \& Darwin, M. (2021). Effect of Work-Life Balance and Welfare Level on Millennial Employee Performance Through Work Engagement. International Journal of Science and Society, 3(1), 334-344.

Richardsen, A. M., Mikkelsen, A., \& Burke, R. J. (1997). Work experiences and career and job satisfaction among professional and managerial women in Norway. Scandinavian Journal of Management, 13(2), 209-218.

Rivai, V., \& Sagala, J. (2011). Manajemen Sumber Daya Manusia Untuk Perusahaan Dari Teori ke Praktik. Jakarta: Rajawali Press.

Robbins, S. P. (2003). Perilaku Organisasi. Jakarta: Gramedia. 
Saparwati, M., \& Sahar, J. (2017, February). Pengalaman Kepala Ruang Dalam Mengelola Ruang Rawat Inap Di RSUD Ambarawa. In Prosiding Seminar Nasional \& Internasional.

Sekaran, U., \& Bougie, R. (2016). Research Method for Business: A Skill- Building Approach. Chichester: Wiley.

Sugiono, E., \& Fitriana, M. (2018). Strategi Peningkatan Kinerja Pegawai Melalui Peranan Budaya Organisasi, Motivasi Dan Kepuasan Kerja Pada Badan Pengembangan SDM ESDM di Kementerian Energi dan Sumber Daya Mineral RI. Ilmu dan Budaya, 41(60).

Sugiyono. (2012). Metode Penelitian Bisnis. Bandung: Alfabeta.

Tabiu, A., \& Nura, A. A. (2013). Assessing the effects of human resource management (HRM) practices on employee job performance: A study of usmanu danfodiyo university sokoto. Journal of Business Studies Quarterly, 5(2), 247.

Warsito, B. (2020). Pengaruh Faktor Pendidikan, Pelatihan, Motivasi dan Pengalaman Kerja terhadap Kinerja Kepala Desa (Studi pada Kepala Desa di Kecamatan Pakis dan Tumpang Kabupaten Malang). Jurnal Aplikasi Manajemen, 6(2), 111-116.

Wijaya, M. (2017). Pengaruh Sistem Rekrutmen dan pengembangan Karir terhadap Kepuasan Kerja Karyawan pada PT. Kimia Farma Plant Medan. JKBM (Jurnal Konsep Bisnis dan Manajemen), 3(2), 123-130.

Wijaya, I. M. B. G., \& Suana, I. W. (2013). Pengaruh Penempatan Dan Pengalaman Terhadap Kepuasan Dan Kinerja Karyawan. E-Jurnal Manajemen, 2(10).

Zahro, H. M., Suyadi, B., \& Djaja, S. (2018). Pengaruh Pengalaman Kerja dan Curahan Jam Kerja Terhadap Kinerja Karyawan (Studi Kasus Pada Home Industry Tas Pita Plastik Bapak Almunir di Desa Setail Kecamatan Genteng Kabupaten Banyuwangi Tahun 2017). Jurnal Pendidikan Ekonomi, 12(1), 8-14. 